\title{
Strategic Tool For Students With Disabilities: Creating And Implementing Virtual Learning Environments Without Barriers
}

Bob G. Barrett, Jr., American Public University, USA

\begin{abstract}
While some organizations have made strides in employing workers with disabilities as an act of social responsibility, other entities have started to realize the need and value of this untapped human resource (Thakker, 1997). Research has shown that employees with disabilities have low turnover rates, low absenteeism, and high motivation to prove themselves (Fersh \& Thomas, 1993). Executives will need to rethink their employment practices in order to compete for employees from the current, shrinking workforce. Further, many employers are looking towards academic institutions for well-qualified employees. The key question here is whether or not our academic institutions and educators are truly prepared to enable, education, and motivate all learners for the changes in the workforce. Specifically, are we able to equip all learners with the necessary technological skills and education to best prepare them for this new workforce outlook? Currently, 54 million Americans with disabilities use information technology (IT) at colleges and universities, which accounts for 20 percent of the population (Oblinger \& Ruby, 2004). Unfortunately, statistical data for persons with disabilities is done with a separate survey, which is a part from the U.S. Survey and conducted only every 10 years.
\end{abstract}

Keywords: Virtual Learning, Disabilities, e-Learning

\section{OVERVIEW}

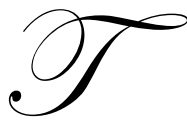

his paper identify a growing need for educational institutions, with current online business and management course offerings, to examine and determine if their current faculty are using e-Learning as a strategic tool, rather than just as another mode of instruction. In particular, this paper will look at the need to use e-Learning as a strategic tool to help engage and enrich the learning opportunities for students with disabilities. Further, it is equally important that this particular student population be engaged with a variety of e-Learning applications, including a global perspective in order to enable and assist them in exploring the possibilities of pursuing not only work within one's country, but also globally or virtually.

This writing will provide an overview of the current needs of e-Learning to be used as another mode of instruction, but also as a strategic tool for breaking down current educational barriers faced by students with disabilities in educational institutions. In addition, to the technological changes in online learning, students are now faced with greater opportunities to pursue employment, both domestically and internationally. In fact, they are able to apply and obtain virtual jobs, which were not available or afforded to their peers in previous decades. In the following section, there will be an overview of the current statistics of people with disabilities in the United States, along with an overview of distance education, which will also be referred to as e-Learning in this paper.

In 2006, 38 states in the United States have established state-led online learning programs, policies regulating online learning, or both. Also, 25 states have state-led online learning programs, and 18 states are home to a total of 147 virtual charter schools serving over 65,000 students (http://www.nacol.org). In 2001, 56\% of 
traditional learning institutions offered distance learning programs. An additional $12 \%$ of schools stated they planned on adding distance learning programs to their curriculum within the next three years (National Center for Education Statistics, 2003). Thus, more secondary- and post-secondary level teachers will need to seek additional education in order to obtain and master quality online teaching skills and strategies. As a result, more universities are offering online education courses and teacher training in order to help recruit and hire more online instructors. Thus, there is a growing need to increase the number of online instructors to teach at many educational institutions. In the following section, we will examine how the current disability statistics in the U.S. signifies a need to make changes in both the workplace and education.

\section{DISABILITY STATISTICS IN THE UNITED STATES}

As noted previously, the statistics done in the area of disability is a bit limited in the U.S. According to the Disability Status 2000, Census 2000 Summary File \#3; and Census 2000 Brief (March 2003) (C2KBR-17), the following statistics about the employment of people of disabilities was noted: "The total number of people with disabilities aged 16-64 is 33,153,211, [of which], the total number employed is 18,525,862. The percent of people with disabilities aged 16-64 employed is 55.8" (Census, 2000, para. 4-6). Further, the reports went on to noted that "18.6 million people disabilities employed aged 16-64, 60.1\% of men with disabilities are employed, and 51.4\% of women with disabilities are employed" (Census, 2000, para. 7). As noted from these statistics, there is still a disparity between the employment rates of people with disabilities versus their able counterparts. However, one way of changing these employment figures may be the use of technology and how it is offered and facilitated with people with disabilities.

The National EmployAbility Partnership (NEP), a program of the National Organization on Disability, has presented a different approach to the statistical outlook for people with disabilities. According to NEP (2008), they noted:

- $\quad$ Studies how that $2 / 3$ of the disability population wants to and can work.

- Yet only one half of $1 \%$ of those receiving public disability benefits (SSI/SSDI/Medicaid and Medicare) ever return to work.

- $\quad$ Between 1990 and 1999, the federal outlay for these public benefits grew from 3.21 billion to $\$ 5.85$ billion each month. Low employment among people with disabilities imposes costs not only on disabled jobseekers, but on American taxpayers (para. 2).

Further, NEP (2008) looked the future statistics on this same population and noted:

- $\quad$ Between now and 2015, as the Baby Boomer generation retires, American industry will need between 10 and 15 million new workers.

- $\quad$ Research shows that people with disabilities have lower rates of turnover and absenteeism and $70 \%$ of workplace accommodations can be made for less than $\$ 500$;

- $\quad$ The ingenuity and problem-solving skills of people who spend their lives adapting to challenges in their environment are assets that can be trained towards high productivity in the workforce (para. 3).

\section{VIRTUAL LEARNING AND DISTANCE EDUCATION}

Neal and Miller (2006) defined distance education as "education that takes place independent of location, in contrast to education delivered solely in the classroom, and that may be independent of time as well (para. 4). ASTD, an education/training \& development professional organization, noted that "distance education can be characterized as an educational situation in which the instructor and students are separated by time, location, or both. Education or training courses can be delivered to remote locations via synchronous or asynchronous means of instruction (Neal \& Miller, 2006, para. 5).

Just prior to this definition, the U.S. Government and Department of Education started to view the value of education and technology in a different light. They realized that technology was the tool to help facilitate learning, as well as prepare students for the workplace. As a result, in the early and mid-1990s, the U.S. Secretary of 
Education released the nation's first educational technology plan in 1996. The Plan was entitled, "Getting America's Students Ready for the $21^{\text {st }}$ Century: Meeting the Technology Literacy Challenge. While this plan was focused on elementary and secondary schools, it did provide a framework for educators on the post-secondary level to consider as they prepare future educators for work on the elementary and secondary school levels. The goals were:

- Goal 1: All students and teachers will have access to information technology in their classrooms, schools, communities, and homes.

- $\quad$ Goal 2: All teachers will use technology effective to help students achieve high academic standards.

- $\quad$ Goal 3: All students will have technology and information literacy skills.

- Goal 4: Research and evaluation will improve the next generation of technology applications for teaching and learning.

- Goal 5: Digital content and networked applications will transform teaching and learning. (www.edu.gov, 2008, para. 7).

\section{VIRTUAL LEARNING ENVIRONMENT AND TECHNOLOGICAL ADVANCEMENTS}

Due to the technological advancements in the online environment, online students must have a different type of skills sets in order to compete in today's online learning environment and workplace. As a result, universities must create and implement different practices and procedures in order to prepare all students, especially students with disabilities, to compete for quality and meaningful employment. Thus, this paper helps to provide an open forum for the reader and others to determine if there is a need for change. If so, it also provides a chance for further research to be conducted to help examine how various schools of business, both traditional and online, can approach the career development segment of their course offerings and programs.

As more technology has become available in many parts of the globe, a new type of student population has emerged. The traditional student image of higher learning has been somewhat limited in many countries, but given the impact of the Internet, this traditional "student body" has changed to online communities. According to Preece (2000), these online communities "consists of people who interact socially as they strive to satisfy their own needs or perform special roles; a shared purpose that provides a reason for the community; policies that guide people's interactions; and computer systems to support and mediate social interaction and facilitate a sense of togetherness" (p. 10). In the field of business and management, educators have recognized the demographical changes of the student population.

While technology has provided a powerful infrastructure, the emerging technologies have allowed educational institutions, educators, and students to achieve education on a much higher playing field - in a virtual learning environment. As a result, more students with disabilities are enrolling in online courses. One reason for this increase in online enrollment is due to online learning environment allowing for more barrier-free opportunities to education for students with disabilities.

The next several sections will cover key issues facing e-Learning in education and with students with disabilities. The following topic areas will be covered.

- $\quad$ Students with disabilities in the learning environment

- Technological changes in the learning environment

- $\quad$ Societal views and changes in the workplace

- $\quad$ Involvement of stakeholders

- Technological Barriers and Improvements

\section{STUDENTS WITH DISABILITIES IN THE LEARNING ENVIRONMENT}

Since the beginning of time, only the strongest of students were educated first. Societal views did change, but the education of students with disabilities changed slowly (Almazan \& Quirk, 2002). In the U.S., the 
introduction of mainstreaming helped to break down some barriers - but not all (Almazan \& Quirk, 2002). While some barriers were attitudinal, the others barriers to education for students with disabilities were in the form of architectural ones. For example, Face-to-Face (F2F) classrooms have not always been conducive to learning. Prior to the passage of the Americans With Disabilities Act of 1990 (ADA), many public and private offices, buildings and schools were not accessible for persons with disabilities. In terms of schools, some of the architectural barriers were the layout of classrooms, restrooms access, and entry to building access (ACCM, 2007). Another barrier in the learning environment was the instructors. The mixing of students with instructors with limited education or training in teaching students with disabilities (whitehouse.gov) was yet another problem. As a result, many disability and education groups (i.e., AHEAD, NDA, NFTB, etc.) have lobbied for changes in the education of instructors teaching all types of students.

\section{E-LEARNING AND TECHNOLOGICAL CHANGES}

As educational reform started to make changes in the classroom, so did technological advancements. Educators and administrators started to see instruction methods moving from a sheet of paper to the computer. The role and function of the technological evolution in terms of the introduction and placement of personal computers in the classroom made a major impact in the field of education. As more technological advancements started to appear, schools stated to find that computers had a larger storage capacity; were cheaper to purchase; easier software was being developed to navigate; students were starting to learn computers at an earlier age; and adaptation of course materials to the computer environment was being made easier for instructors.

As a result of many technological advances, schools systems still had to face other problems due to poor planning and budgetary constraints. The number of computers also limited the number of users. Also, due to budgetary problems, sometimes there was a limited use of software licenses due to the amount of budgetary investment. Further, the limited training given to some instructors did impact how many students would receive instructions. On the other hand, some computers were not fully accessible for students with disabilities. Finally, some instructors were not trained to teach students with certain types of disabilities wishing to learn and operate computers and various computer software packages. These problems represented only a few reasons why many school systems sought additional funding to increase e-Learning opportunities for all students.

\section{Current Technological Barriers and Improvements}

As more computers were being adapted or manufactured to become more accessible for people with disabilities, there were some other barriers. First, some computer hardware and software offerings were still much too expensive for some students and school systems. Second, many instructors were not aware of the many technological possibilities that are available at the current time (EnableMart, 2007). This helped to start a movement on many college campuses to become more proactive in using e-Learning as a strategic tool for students with disabilities (www.ahead.org).

During this time, educational institutions started to develop technological partnerships with major industry leaders and disability groups for a variety of reasons. Some major companies offer special grants and funding for students with disabilities (and school systems). Disability organizations make good partners for schools and instructors who want to help their students with disabilities to achieve even more with their educational endeavors. Some organizations may be able to offer not only technological equipment and software, but they may be interested in offering volunteers to help train teachers and students with certain technological applications. These technological partnerships were important to several stakeholders - the schools, industry, and students with disabilities. The key here was to bring together interested parties to help develop and implement e-Learning for all learners.

\section{Creating E-Learning Applications}

E-learning is not for all students. However, for students with disabilities, the many facets or approaches that e-Learning offers more opportunities than ever before. For example, visual learners were able to benefit from applications in PowerPoint and Flash Multi-Media technology. Auditory learners could benefit from online 
classrooms with auditory lectures, Podcasts for students, as well as live chats. From a blended-approach perspective, some online programs offer both auditory lectures, as well as PowerPoint slide presentations. Also, live chats (both auditory and visual - i.e., Elluminate, Horizon Wimba, etc) offer more opportunities for a variety of learners.

\section{Is E-Learning Helping Students with Disabilities to Learn and Prepare for the Workforce?}

In light of technological changes, distance education has transformed over the past several decades. The new buzz word for distance education is e-Learning -due to the many opportunities provided to all students through this electronic learning format. The following list is an overview of the skills, abilities, and knowledge gained by students with the use of e-Learning and online course formats.

- $\quad$ Skills

- Computer skills in terms of learning and operating software and hardware

- $\quad$ Abilities

- Ability to manipulate data

- Ability to operate various types of computer programs

- Ability to create, manage, send, and analyze data

- Ability to surf the Web and discover even more about learning and the world around them

- Ability to search, analyze, distinguish and use information gathered on the Internet

- $\quad$ Knowledge

- Students are more knowledgeable of current technological offerings and changes in the workplace than ever before.

- Students with disabilities are now able to compete more in the learning environment - with the implementation of E-Learning. E-Learning has helped to create a more level field of learning for these students.

- Students can effectively use course knowledge and apply it to real work applications.

- Case in point - recent supervision of a master's mini-thesis completed by a visually impaired student (Barrett, 2007).

\section{UTILIZING E-LEARNING AS A STRATEGIC TOOL FOR DIVERSITY AWARENESS AND ACCOMMODATION}

In addition to being a strategic tool for learning, e-Leaning offers a good platform for education a variety of students, faculty, and administrators in the areas of diversity awareness and accommodation. The following points represent how e-Learning can be used to help educate all users - as well as serving as a training tool to illustrate how societal views are changing or need to change.

- $\quad$ E-Learning is a technological tool, as well as a tool for learning and socialization.

- $\quad$ E-Learning can be used to educate not just one group of learners - but many others.

- $\quad$ E-Learning can help to promote "diversity awareness."

- $\quad$ E-Learning can help to accommodate learners with disabilities and accommodate the needs of instructors and educational institutions.

- $\quad$ Is E-Learning at its prime or still in its infancy stage in terms of helping all types of learners?

- $\quad$ Can e-Learning help to break down barriers and be used as a tool to increase our knowledge base by including the viewpoints of a more, diversified group of learners?

- Finally, is e-Learning a strategic tool that benefits business more than education?

\section{CONCLUDING THOUGHTS AND REFLECTION}

Can E-Learning be used as a strategic tool for students with disabilities? Yes, it can, but educational institutions may need to rethink how they present material and in what types of software applications. Can students with disabilities help to solve problems in the classroom and break down even more barriers? With the use of e- 
learning, more and more students (of all abilities) are now able to participate in learning. Further, e-Learning has provided many unique and creative opportunities for instructors and learners to learn and grow from each others personal and professional experiences.

What can we, as stakeholders, do to help improve the learning environment and use of E-Learning as a strategic tool for change? This depends on our philosophy of learning, commitment to teaching, and ability to make changes in the learning environment.

\section{AUTHOR INFORMATION}

Dr. Bob Barrett is a professor in the School of Business at the American Public University. Dr. Barrett's current research interests are: Online Learning, Intellectual Capital, Human Resource Development (HRD); Human Resource Management (HRM); Virtual Management Teams; Disability in the Workplace. He speaks both nationally and internationally on these topics, with an emphasis on online learning, disabilities, and intellectual capital/knowledge management. Dr. Barrett currently teaches and writes on the subject of global business in today's changing economic times. E-mail: docjob00@msn.com

\section{REFERENCES}

1. AHEAD. Retrieved Jan. 15, 2008 from www.ahead.org website.

2. Alleghany Community College of Maryland. Assistant students with disabilities: A faculty \& staff guide book. Retrieved July 1, 2007, from http://www.ac.cc.md.us/iac/studdisability_faculty.pdf.

3. Almazan, S. \& Quirk, C (Ed.D.) (2002). Historical and legal perspectives: Court cases, federal law and educational practices related to the education of students with disabilities. Retrieved July 12, 2007, from http://www.mcie.org/docs/publications/Historical_LegalPerspectives.doc.

4. Barrett, B. (1999). A case study: Best disability employment practices. Washington, DC.

5. Boyett, J.H., Boyett, J.T. (1995). Beyond workplace 2000: Essential strategies for the new American corporation. New York: Dutton.

6. Disability Status 2000, Census 2000 Summary File \#3; and Census 2000 Brief (March 2003) (C2KBR-17) Retrieved on March 20, 2008 from http://www.dol.gov/dolfaq/go-dolfaq. asp?faqid $=66 \&$ faqsub $=$ Statistics\&faqtop=People+with+Disabilities\&topicid $=11$.

7. $\quad$ EnableMart (2007). EnableMart Catalog, Vancouver, WA.

8. National Organization on Disability (www.nod.org) (2008). National EmployAbility Partnership (NEP). Retrieved on March 20, 2008 from http://www.nod.org/index.cfm?fuseaction=Page.ViewPage\&PageID=1556.

9. Oblinger, D. \& Ruby, L. (2004, January). Accessible technology; Opening doors for disabled students. Retrieved March 1, 2008 from http://www.nacubo.org/x2074.xml.

10. Neal, L. \& Miller D. (2006). The basics of e-learning: An excerpt from Handbook of Human Factors in Web Design, para. 4-5. In R.W. Proctor \& K.L. Vu (2004), Handbook of Human Factors in Web Design, Lawrence Erlbaum Associates. Retrieved March 19, 2008 from http://www.elearnmag.org/subpage.cfm?section=tutorials\&article=20-1.

11. Preece, J. (2000). Online communities: Designing usability, supporting sociability. Chichester: Wiley.

12. White House. A quality teacher in every classroom: Improving teaching quality and enhancing the profession. Retrieved June 15, 2007, from http://www.whitehouse.gov/infocus/education/teachers/qualityteachers.pdf

13. U.S. Department of Education (2008). E-Learning: Putting a world-class education at the fingertips of all children. Retrieved on March 16, 2008 from http://www.ed.gov//about/offices/list/os/technology/reports/elearning.html. 